\title{
Lisbon Agenda and public administration
}

\author{
Wolfgang Drechsler
}

Public administration and the Lisbon Agenda, 2000-2007

The life-world of the Lisbon Agenda, today's Europe, can be described as a primarily administered environment. In spite of all criticism of the public sector and its organization, it retains its significant, often dominating role in economy and society. It is therefore baffling that the original Lisbon Strategy does not address this subject at all, nor was this remedied in the Kok Report or any other documents until 2005. In that sense, public administration was the missing dimension of the Lisbon Agenda.

Only from 2006 do we see a trickle of mentions of public administration in Lisbon Agendarelated documents, especially as concerns its role in innovation (which is very different from 'innovative practices in public administration'). The Implementation Report 2006 states that there is a role of the public sphere in the innovation process (p. 17), and the Lahti conclusions (2006, pp. 6-7) likewise acknowledge this role. In all the documents that mention the Lisbon Agenda, including later ones, even if they are not factually linked, the same tendency is visible: A focus on e-government, public procurement, and innovation (usually very loosely understood).

\section{The European Public Administration Network}

At the same time, in Lisbon Agenda scholarship, too, neglect of public administration was the case; there has been virtually no attention given to the subject matter. The main exception is the work by Kalle Määttä $(2004,2006)$, which is very strongly policy-oriented. This work was done in the context of the one institution that has addressed the topic fairly early on, EPAN (or EUPAN, the acronym seems to vary), "an informal network of Directors General responsible for Public Administrations in EU member States and European Commission" (http://www.eupan.org), which is in fact the main institution on the European level, if with no legal basis or staff and completely voluntary, to deal with the issues.

During the Luxembourg presidency, and chaired by it, EPAN formed an ad-hoc group on the Lisbon Strategy that worked for half a year in 2005; the results (EPAN 2005) do not seem adequately reflected in the further discussion of public administration within the Lisbon Agenda in the EU context.

The "Wassenaar Memorandum of Understanding" (November 2004) had established the Lisbon Agenda as a main point of reference, arguing for "the importance of an excellent functioning public administration as a contributor to realising the Lisbon Strategy." (EPAN 2005, p. 22) The final report of the ad-hoc group states that "Implementing some of the key Lisbon priorities depends on a highly competent, professional and competitive public administration, being characterised by effective governance structures, innovative and effective policy-making practices and a performance oriented service delivery. In this sense 
the national public administrations are to be considered as important enablers for reaching the Lisbon targets.” (p. 5)

What we can learn from the EPAN and Määttä is the significance of public administration for the Lisbon Agenda in its different aspects (to which we will later add public administration's key role in innovation):

Table 1: The significance of public administration for the Lisbon Agenda

Public administration...

\begin{tabular}{|l|l|l|}
\hline General & In the EU & For the Lisbon Agenda \\
\hline $\begin{array}{l}\text { as a central part of public } \\
\text { governance }\end{array}$ & $\begin{array}{l}\text { as the largest employer in the } \\
\text { EU }\end{array}$ & $\begin{array}{l}\text { as the main service provider } \\
\text { especially in the key areas of } \\
\text { the Lisbon Agenda } \\
\text { (education, health care, } \\
\text { social protection) }\end{array}$ \\
\hline $\begin{array}{l}\text { as context creator for citizens } \\
\text { and businesses to act }\end{array}$ & $\begin{array}{l}\text { as a large spender/purchaser } \\
\text { (more than 15\% EU GDP } \\
\text { overall) }\end{array}$ & $\begin{array}{l}\text {.. and governments as the } \\
\text { designers of the Lisbon } \\
\text { Agenda }\end{array}$ \\
\hline $\begin{array}{l}\text { as service provider } \\
\text { (hindering role as well as } \\
\text { positive one) }\end{array}$ & $\begin{array}{l}\text { as the largest single industry } \\
\text { in the EU (45\% EU GDP } \\
\text { overall) }\end{array}$ & \\
\hline
\end{tabular}

(EPAN 2004, pp. 2-3; Määttä 2004, pp. 4-6; 2006, pp. 29, 58-59)

\section{Public administration in the Lisbon Agenda today}

By 2008, public administration still plays a very minor role in the Lisbon Agenda context, but it now does play a role, much of it a result of the Portuguese presidency's initiative in this field. There have been specific meetings and policy papers (Initiatives 2007), especially as regards the Member States and the National Lisbon Programmes; and public administration is an issue, if not a top priority, in the results report of the presidency as well. (Preparing 2007)

We can categorize public administration as it relates to the Lisbon Agenda into four basic categories:

Table 2: Categories of public administration in the Lisbon Agenda context

\begin{tabular}{|l|c|c|}
\hline Public administration & of the Lisbon Agenda & in general \\
\hline on the Member States' level & $\mathbf{1}$ & $\mathbf{2}$ \\
\hline on the EU level & $\mathbf{3}$ & $\mathbf{4}$ \\
\hline
\end{tabular}

If we do so, we see that the current focus is almost exclusively on 2, with some attention to 1 and none to 3 or 4 . We can further say that none of the Lisbon-related public administration documents address the structure and organization of public administration, except in very general terms; partially, this may have to do with the highly national quality of the civil service structure. Rather, tools and methods have been the main focus. A link to the current 
debate about the shifting character of the public administration paradigm, especially in Europe, seems to be almost completely missing; this short paper will attempt to supply it.

If we look from a public administration perspective at all the papers and documents mentioned, we also notice three significant aspects: public administration is generally viewed synonymously with public policy, and it is understood within a (public) finance framework, mainly aiming at its reduction and (streamlining, customer-oriented) reform, often said to (indirectly) aid the innovation process. We also see that what is striven for is throughout a 'modernization', so as to arrive at 'modern' and 'innovative' public administration. And in general, it seems that institutions are seen more as barriers to growth and innovation than enablers.

\subsection{Policy}

Even, perhaps especially, the very best documents connecting public administration and Lisbon Agenda do so from a policy perspective. For instance, Maria João Rodrigues’ proposal (2008) for improving public administration for the Lisbon Agenda focused exclusively on planning and strategic management. (pp. 9-17). Even when taking into consideration the many problems with strategic planning, this is undoubtedly important, but it does not address the main issues of public administration. The same, if on a much more tool-based level, is the case with all other documents as well, best perhaps in Määttä (2004, also 2006). Obviously, then, there is a tacit conflagration of public administration with public policy. Yet, while the two overlap and always have overlapped, the clear recognition of public administration, its basically implementational character, the difference between administration and policy (Hegel 1821, § 287 is the classic statement), is important to retain in order to keep one's focus on questions of staff and organization - the 'who' rather than the 'what', because there is no 'what' without the 'who' -, indeed of civil service structure, because administration is not policy but its exercise. A concentration on policy obscures the nature of and demands on administration itself, to the detriment of whatever the project at hand is. So, in the Lisbon Agenda context, while policy is important, it is necessary to look at public administration proper in order to see who implements it, and how.

\subsection{Finance}

As regards the finance context, a particularly strong example is the main paper to prepare a meeting on these issues (Initiatives 2007), where public administration reforms are seen, fundamentally, as a money-saving device, together with lifting a bureaucratic burden. The final report of the Portuguese presidency on the Lisbon Agenda (Preparing 2007), in turn, lists a "need for stronger action" in public administration, specifically "public administration modernization,” (Preparing 2007, Main Outcomes, p. 1) but the statement remains largely fiscal: "The modernisation of public administration is key to improve efficiency and effectiveness of public finances.” (p. 3) Reported as a main result of the $2822^{\text {nd }}$ Council meeting is "the reform and modernisation of public administration. The conclusions highlight the importance of such initiatives in enhancing competitiveness, delivering better services, achieving better value-for-money and ensuring the control of government expenditure, and thus meeting the objectives of both the Lisbon strategy for growth and jobs and the stability and growth pact." (p. 2) The following statement is typical: "The Council discussed Member 
States' experiences of modernising public administration in the context of the quality of public finances.” (p. 12) It does address “a re-organisation of public administrations” (12), but what this should look like, and why it should take place, is not specified. It even recommends having the Ministers of Finance play a key role in public administration reform (p. 12), a move that historically has almost universally led to disaster, because ministries of finance are by their self-logic interested in cost-cutting, neither in value-creation nor in the support of innovation. Finally, public administration is mentioned in the March 2008 Presidency Conclusions only in the context of improving the quality of public finances. (p. 3) However, public administration can only be judged, in financial terms, by the wealth it creates, and so the question is not how much can be saved here, but how much return one receives from investing. (This is of course difficult to ascertain, let alone measure, but this does not affect the principle.) To save by cutting public administration may be foolish if this leads to lower productivity, entrepreneurship, innovation, or economic development - and there are good reasons to think that such a connection exists.

\section{3 'Modern' and 'innovative' public administration}

Most importantly, however, what is emphasized in general and overarching as a claim is the need for a 'modernization' of public administration. Every single document that addresses public administration talks about 'modernization'. However, what does 'modern' really mean? Almost no document gives as much as a working definition of the concept, and the one that does, "Intitiatives" (2007, p. 4), states that "In a broad sense, the modernisation of public administration can be defined as reform measures aimed at improving the quality of governance and at raising the efficiency and effectiveness of public service provision.” This is both highly reductionist and completely vague, because neither is merely the quality of public administration the issue, nor is public administration exhaustively described by service provision.

In any meaningful sense in this context, 'modern' can not mean anything specific, but 'in line with the times', 'in line with the current situation.' 'Modern' in the sense of 'new' is surely not only an ambiguous, but also a highly ambivalent concept by now, after the experiences of the $20^{\text {th }}$ century - would a totalitarian shift away from democracy be better because it was the new thing? What, if not 'appropriate for the circumstances of the times', could 'modern' mean except merely 'fashionable'? What would be bad about an appropriate, well-working, traditional solution? What is appropriate, however, depends on the times and the situation, and the problem is that the vast majority of claims in documents surrounding public administration use 'modern' to denote a concept that is exactly not in line with times and situation at all.

In addition, as in so many areas of the public discourse during the last decade or two, what we generally see is a very loose deployment of the concept of innovation. Innovation, however, has to be understood quite strictly - in a basically Schumpeterian sense, of course with some modifications and additions - if the effects, the reasons why innovation is so important and central, not least for the Lisbon Agenda, are going to be harvested at all. Within and concerning the public sector, the use of the term is just that of wielding a cliché - it means 'something new', nothing more, interchangeable with 'modern'. Yet, again, in public administration, it is definitely enough if some arrangement works, or works well; there is no reason that it has to be new, let alone genuinely innovative, if this could ever be. Surely, the 
public sector has to go with the times, it is not immune to the demands of the "new best practice" in organization (Perez 2002), but this is vastly different from being innovative in itself. Innovation is about profit, and the task of the state is neither to make money, nor to save it, but - as one aspect - to see that it can be and is made.

In the public administration context, this is no light matter, a fortiori as far as the Lisbon Agenda is concerned, with its emphasis on an innovation-based economy. The problem is that within public administration, the paradigm, as has already been mentioned, has changed in the past few years, yet the Lisbon Agenda public administration discourse does not reflect that change. Rather, it is heavily retrospective and basically presents a public administration that is - not in specific areas, such as e-Governance, but in principles and structure - designed to solve the problems of the 1970s and 1980s, whose chance of coming back is very slight indeed.

\section{The New Public Management and its demise}

Within public administration, the most important reform movement of the last quarter of a century has been the New Public Management (NPM), the basis of all Lisbon Agenda public administration initiatives, as it seems. NPM is the transfer of business and market principles and management techniques from the private into the public sector, symbiotic with and based on a neo-liberal understanding of state and economy. The goal, therefore, is a slim, reduced, minimal state in which any public activity is decreased and, if at all, exercised according to business principles of efficiency. It is popularly denoted by concepts such as project management, flat hierarchies, customer orientation, abolition of career civil service, depolitization, total quality management, and contracting-out. Transparency, citizen involvement, and decentralization are not part of the original core of NPM, both theoretically - because the NPM's focus on the apolitical rule of the expert makes them more difficult and because they do not necessarily contradict previous forms of public administration at all - and empirically.

NPM comes from Anglo-America, and it was strongly pushed by most of the International Finance Institutions such as the World Bank and the IMF. It originates from the 1980s with their dominance of neo-liberal governments and the perceived crisis of the Welfare state and its financing, but it came to full fruition in the early 1990s. NPM was on the one hand a fashion phenomenon within public administration scholarship and practice, which explains much of its power; on the other, a genuinely ideological concept.

As important and, though more rarely, as successful as several NPM-inspired reforms of the public sector might have been and still may be, what one notices first when looking at the public and private spheres is the difference, not the similarity. The state is denoted primarily by its monopoly of power, force, and coercion on one side and its orientation towards the public good, on the other; the business world legitimately focuses on profit maximization. The use of business techniques within the public sphere thus confuses the most basic requirements of any state, particularly of a Democracy, with a liability: regularity, transparency, and due process are simply much more important than low costs and speed.

This is why respective economic and especially management-theoretical insights could only establish themselves after the end of the dominance of the NPM, which as genuine ideology was not open even for arguments stemming from its own leading method. NPM reforms 
created, for instance, quasi-markets within administrative organizations in order to create market behaviour: yet, such behaviour can only develop in genuine and not in quasi- (i.e. pseudo-) markets. (See König 2001, pp. 6-7) Another example is the problem of the concept of performance pay vis-à-vis the demands of multitasking and motivation through identification with the organization (Akerlof and Kranton 2003, esp. pp. 9-11, 27-29); as Lawrence Lynn, Jr., has recently pointed out (Bouckaert et al. 2009), if any concept in the social sciences is disproved, it is that of performance pay - and yet it is politically pushed and implemented - also very frequently within the Lisbon Agenda context, at least in theory.

In advanced public administration scholarship itself, then, especially - but not only - in Europe, NPM is heavily on the defensive by now, if taken as a world view (i.e. an ideology), rather than as one of several useful perspectives for public administration reform (i.e. a tool box). What was an option ten years ago is simply not an option anymore today. One could say that in public administration

- $\quad$ around 1995, it was still possible to believe in NPM, although there were first strong and substantial critiques

- around 2000, the year of the Lisbon Agenda, NPM was on the defensive, as empirical findings spoke clearly against it as well

- around 2005, the year of the mid-term review, NPM was not a viable concept anymore

In other words, it has become quite rare in the last five years, and is becoming rarer still, to see articles in the very top journals, or essays and keynote addresses by the very top public administration scholars - especially in Europe, but also in the United States -, based on, or implicitly assuming the validity, of NPM. Yet, in many areas, both of scholarship and of the world, and particularly in policy, NPM is very alive and very much kicking (i.e. the farther one is from academe, Europe, or international and central government, the first element being the most crucial). This is also true on the level of the EU and many Member States, where it fits some strings of the dominating world view(s). Nevertheless, especially on the local and regional level, many communities have in recent years, and after careful deliberation, acted against NPM reforms, even in traditional NPM strongholds. The justification for stopping the NPM reforms by the city of Dübendorf, Zürich, Switzerland, sums up the reasons very nicely: "no improvements of efficiency, effectiveness nor quality could be attributed to NPM reforms.” (Noordhoek and Saner 2005, p. 38)

\section{The Neo-Weberian State}

The counter-model to NPM, indeed its bête noire, is what is called 'Weberian public administration'. This label is highly problematic, as NPM presents a caricature of it and thus builds up a paper tiger. Apart from the caricature, for Weber, the most efficient public administration was a set of offices in which appointed civil servants operated under the principles of merit selection (impersonality), hierarchy, the division of labour, exclusive employment, career advancement, the written form, and legality. This increase of rationality his key term - would increase speed, scope, predictability, and cost-effectiveness, as needed for an advanced mass-industrial society. (Weber 1922, esp. pp. 124-130)

It seems that fundamentally, with all its weaknesses, the Weberian model still seems to be the best around, and it is certainly superior to the NPM - it is, to borrow the Churchillian phrase, 
the worst form of public administration except all others. The connection between Weberianism and economic growth seems, in any case, very close. (See Evans and Rauch 1999) Nevertheless, the optimal administrative structure of our times does not comprise of a simple rehash of the organization principles of the mass production paradigm, whose weaknesses are amply known - from excessive legalism via genuine bureaucratism to genuine antagonism to innovation and the economy. NPM also offers quite some - i.a. managerialist elements and even larger principles which 'as such' could be judged positively, as long as they do not form the basis of the system, and there have to be some adaptations for the current times and their different challenges, demands, and socio-intellectual context.

This is why the currently most discussed model for the administrative paradigm that follows NPM, i.e. 'post-NPM', is not a return to the previous one, but according to the concept of Pollitt and Bouckaert of 2004, the so-called Neo-Weberian State (NWS), a fortuous metaphor describing a model that co-opts the positive elements of NPM, but on a Weberian foundation, i.e. that both are asymmetrically aufgehoben. (Pollitt and Bouckaert 2004, pp. 96-102) One can briefly sum up the NWS as follows:

Table 3: The Neo-Weberian State (summary)

\begin{tabular}{|l|l|}
\hline Neo- & Weberian \\
\hline $\begin{array}{l}\text { Shift from an internal orientation towards } \\
\text { bureaucratic rules to an external orientation } \\
\text { towards meeting citizens' needs and wishes. } \\
\begin{array}{l}\text { The primary route to achieving this is not the } \\
\text { employment of market mechanisms } \\
\text { (although they may occasionally come in } \\
\text { handy) but the creation of a professional } \\
\text { culture of quality and service }\end{array}\end{array}$ & $\begin{array}{l}\text { the main facilitator of solutions to the new } \\
\text { change, shifting demographics, and } \\
\text { environmental threat }\end{array}$ \\
\hline $\begin{array}{l}\text { Supplementation (not replacement) of the } \\
\text { role of representative democracy by a range } \\
\text { of devices for consultation with, and direct } \\
\text { representation of, citizens' views (...) }\end{array}$ & $\begin{array}{l}\text { [but:] Reaffirmation of the role of } \\
\text { representative democracy (central, regional, } \\
\text { and local) as the legitimating element within } \\
\text { the state apparatus }\end{array}$ \\
\hline $\begin{array}{l}\text { In the management of resources within } \\
\text { government, a modernization of the relevant } \\
\text { laws to encourage a greater orientation on the } \\
\text { achievements of results rather than merely } \\
\text { the correct following of procedure. This is } \\
\text { expressed partly in a shift from ex ante to ex } \\
\text { post controls, but not a complete } \\
\text { abandonment of the former }\end{array}$ & $\begin{array}{l}\text { suitably modernized - in preserving the basic } \\
\text { principles pertaining to the citizen-state } \\
\text { relationship, including equality before the } \\
\text { law, legal security, and the availability of } \\
\text { specialized legal scrutiny of state actions }\end{array}$ \\
\hline $\begin{array}{l}\text { A professionalization of the public service, } \\
\text { so that the 'bureaucrat' becomes not simply } \\
\text { an expert in the law relevant to his or her } \\
\text { sphere of activity, but also a professional } \\
\text { manager, oriented to meeting the needs of his } \\
\text { or her citizen/users }\end{array}$ & $\begin{array}{l}\text { [but:] Preservation of the idea of a public } \\
\text { service with a distinct status, culture, and } \\
\text { terms and conditions }\end{array}$ \\
\hline
\end{tabular}

(Pollitt and Bouckaert 2004, pp. 99-100) 
The NWS was intended as an empirical-analytical, not as a normative model, and one of its creators, Pollitt, is quite self-critical about several of its aspects (see Bouckaert et al. 2009), but it stands so far as one explanatory model of what is going on in Europe, and it does not throw good managerialist - and participatory - babies out with the NPM bathwater. It does still form a research agenda, but in lieu of anything better, it significantly helps our understanding of contemporary public administration.

\section{The Neo-Weberian State and innovation}

But why is the NWS so particularly appropriate for the Lisbon Agenda? This is because it is the perfect match for an innovation-based society, contrary to NPM. When dealing with innovation-based economics, the foundation, after all, of the Lisbon Agenda, what none of the papers and documents mentioned seem to see is the immense push-pull function of what is after all a state-based socio-economic development programme that asks for, draws upon, and requires a highly competent, long-term-oriented, dedicated and enabled civil service to implement it - “the Lisbon strategy does not happen by itself” (Määttä 2006, p. 52; see p. 59) - not without the societal actors either, but certainly not without public administration. To say that "Empirical research indicates that modern and efficient public administrations have a positive impact on productivity and growth" (Initiatives 2007, p. 3) is by far too little; it is effective public administration that has this effect, and it is more than a positive impact, but rather a conditio sine qua non. Innovation in the general interest, rather than that of an individual entrepreneur, is a question of successful innovation policy, and who should implement that if not the admininistration? L'innovation, une affaire d'état, as Claude Rochet puts it succinctly. (2007)

If we follow Carlota Perez' great surges theory and her model of Techno-Economic Paradigm Shifts (2002), we can also observe that, as we are in the middle of the ICT paradigm and heading towards a new one in the distance, at this moment, after the collapse and before heading towards "synergy," state and administration are expected to take up their great tasks again and the anti-state climate of the earlier installation period of ICT is, or should be, over. And whatever the new leading technology will be - nanotech, biotech, convergence or something completely different - its setup will require a particularly capable state actor and a science and technology policy implemented by a civil service that is denoted by long-term thinking, high competence, and tolerance for mistakes - the opposite of NPM. (Drechsler 2008)

Finally, it should be emphasized for the current paradigm, that of ICT, that e-Governance and NPM are actually not related, as is usually assumed because they seem to share certain features. (See Dunleavy et al. 2005) Even almost none of the traditional Weberian categories become obsolete through ICT (potentially, exclusive employment does, which may be a problem for the nucleus of civil service), some - such as the written principle and division of labour - are actually enforced. In the most prominent case of hierarchy, there are mixed dynamics, as it is weakened by network models of organization but strongly enforced via the extreme control and coordination capabilities of ICT. But in sum, e-Governance and the NWS can reinforce each other, and in fact seem to do so.

\section{$7 \quad$ Public administration and Lisbon Agenda}


And yet, in the papers mentioned so far, as we can see, NPM is clearly still the basis of all public administration considerations, if often already in a weakened form (such as in Määttä 2006 and Initiatives 2007), but a reorientation towards the NWS, or toward any post-NPM paradigm, has not taken place yet.

\subsection{In the Member States}

But what do the public administration reform initiatives in the Member States look like? While the "Initiatives" paper gives some descriptions and a narrative list of the measures (2007, pp. 4-10,13-14), a more comparable list would be helpful to see what happens, and thus, Thomas Duve has investigated this ${ }^{1}$ with the following results:

Table 4: Public administration reforms and NPM bias in Member States' National Lisbon Programmes, 2006

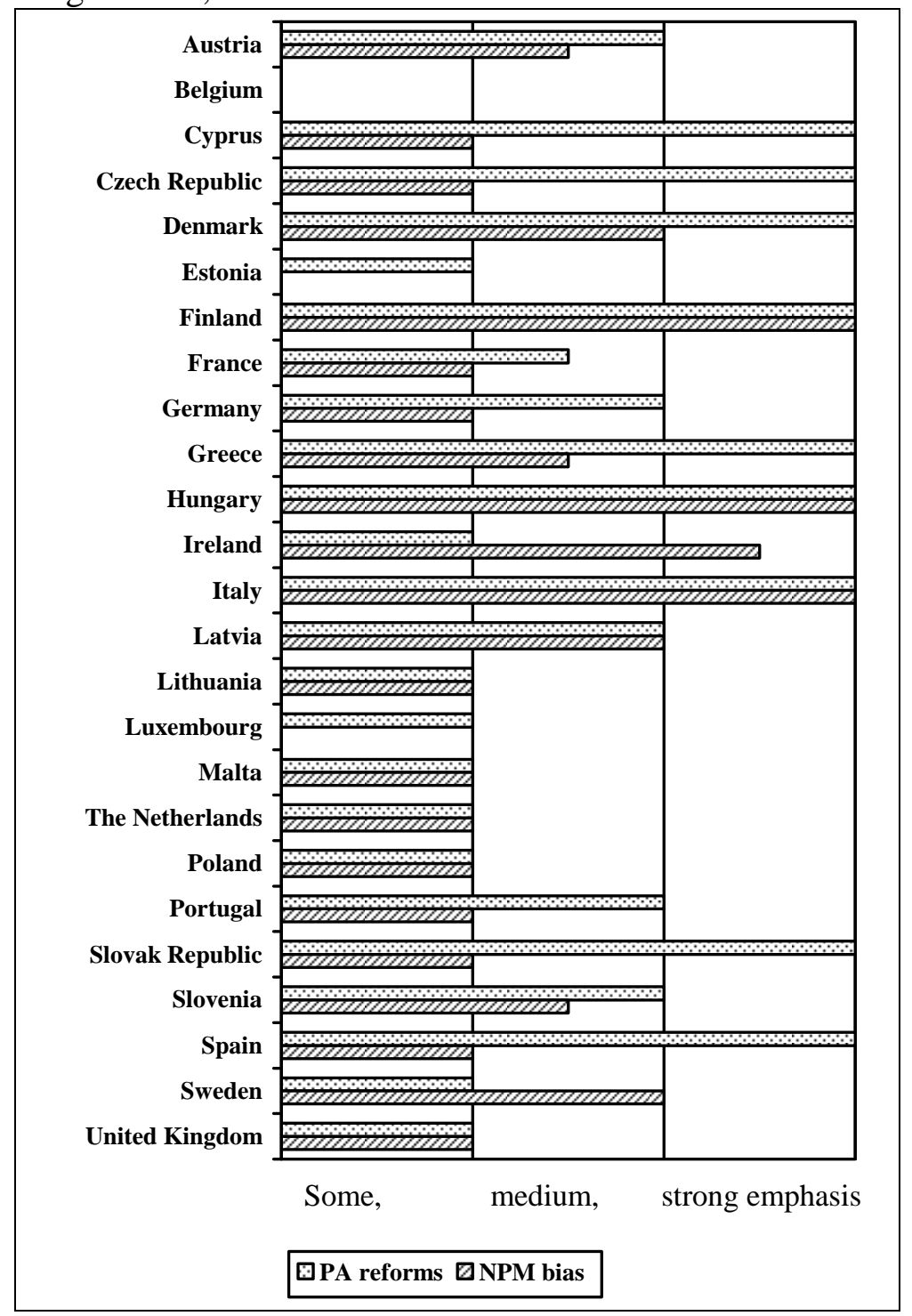

\footnotetext{
${ }^{1}$ Duve 2008; quantitative-qualitative study (in the context of the Estonian Science Foundation project, "Public Administration and Innovation Policy”, Tallinn University of Technology), looking for the frequency of general public administration reform keywords and then NPM ones in the 2006 National Reform Programmes (most recent available data, estimate for France, as the French programme is not available in English).
} 
Contents-wise, e-Government initiatives (against which really nobody will put up resistance anymore) and one-stop shops (which are, in the end, NPM tools but good ones, if rather obvious and simple) as well as the reduction of bureaucracy are the dominant features. We do see, however, some tendency that countries with strong public administration reform activity also verge towards NPM.

The strongest NPM protagonists according to this study, Finland, Hungary, and Italy, are interesting in that they are very different. The Finnish model is to a large extent sui generis and happens on a very solid basis that can 'afford' NPM; also, in the Finnish scholarly public administration discourse, the end of NPM is very well understood, and the tendency, except perhaps on the municipal level, is ending - Finland is not for nothing by most indicators the most successful country in Europe, if not the world. ${ }^{2}$ As regards Hungary and Italy, further studies are necessary, but it may not be too far off the mark to lump these initiatives under the heading of politics and rhetoric; both have very strong, classic systems (in the case of Hungary, consciously created after Weberian models; Italy, rather pre-Weberian) which do not seem to give way to fundamental reforms at the moment.

One should generally consider that (a) these are, again, programmes and not actually implemented reforms, which tend to be very different in public administration, and that (b) it is never clear which kind of public administration reforms were already pursued and then written into the Lisbon Agenda reports. Nonetheless, what we do see, no doubt, is an influence - if perhaps only declarative and performative - of the EU, via the Commission, on national administrations on the basis of the Lisbon Agenda. The ample literature on the Europeanization on national administrations has not touched this matter yet, but this may only be a matter of time. If we look at our matrix, we see that the focus was mostly on category 1 , public administration as such on the Member States' level; the issue of specific Lisbon Agenda administration, category 2, is not really considered yet, either.

\subsection{In European Union administration}

But if category 1 is neglected, we do not find anything about public administration reform on the EU level, i.e. as regards the administration of the Lisbon Agenda by the Commission and the EU administration itself. (From the Commission's point of view, while categories 1 and 2 do not have a responsible Directorate General; 3 - practically to a very small extent - and 4 are located in the DG Admin, the DG for Personnel and Administration; responsible Commissioner is Vice President Siim Kallas.)

We may say that there is no thinking about Lisbon Agenda administration within the Commission, category 3, at all, or at least it is not visible, but that category 4 has been a subject of great attention, especially because this is also a popular issue (in the sense of a genuine general popular animus against “the bureaucrats in Brussels"). It is well-known, or at

\footnotetext{
${ }^{2}$ For me personally, it was clear that NPM had ended when a leading civil servant in the Finnish Ministry of Finance emphasized to me that Finland would use NPM tools rather than the ideology, and when a PhD student from the University of Helsinki referred to certain faculty members as holding "traditional" views, with which he meant NPM.
} 
least the general opinion, that basically, the EU staff formed a Continental civil service system, even among French lines, and proverbially bureaucratic. Partially to cater to fashion and driven by scandal, partially for serious reasons, there have been serious reforms, especially under the previous Commissioner in charge, Neil Kinnock, in 2000. More or less, these were managerialist reforms along NPM lines that were imposed from above. EU scholarship has basically praised the Kinnock reforms, either as a success or, if not, then as well-intended. (For all Bauer 2006)

But by now, some shift, if not explicitly, towards the NWS is visible here as well. Commissioner Kallas, historically very sympathetic to NPM reforms, has recently emphasized that at least the senior civil service of the EU will remain a career system and will be, in fact, even more so than it has been in the past, with a strong emphasis on career advancement, identity, motivation, and precisely not recruitment from the Member States which has led to all kinds of problems, including cultural adaptation. (Kallas 2008; cf. Bauer 2006 for the previous situation) In part, this is seen as a reaction to the problems of the Santer Commission's stepping back after the Cresson scandals in 1999. In spite of all the NPM tools tried, what we can see here is a return to classically Weberian patterns (also echoing Akerlof) with a clear goal in mind, never mind what tools it takes to accomplish it. A transfer from these insights to the Member States may, however, take a while, because this could look to some not as a genuinely progressive shift from NPM to the NWS but rather as a turn backwards to bureaucratic rule.

\section{$8 \quad$ Prospects}

In sum, in spite of a change of focus for the good, we may say that the public administration context of the Lisbon Agenda is still not adequately represented. What is necessary, first of all, is to realize the importance of public administration for the Lisbon Agenda - it cannot succeed without high-quality public administration. Then, it needs to be clear that public administration is not policy, that it is not there to save money but, if anything, to enable the creation of wealth, and that 'modern' should mean 'appropriate for the times'. If one then considers the advances of public administration scholarship, it will be very clear that what is needed for the Lisbon Agenda is a kind of public administration that is NWS-based - on the EU level as well as on the Member States' one.

As regards the latter, again, this is a contentious subject because the field is seen, partially rightly, as a national specific that should not be interfered with by the EU. On the other hand, if the success of the Lisbon Agenda hinges on high-quality public administration, then this is an issue that concerns the entire EU, and therefore there is a certain mandate as an outcome of the Portuguese presidency as mentioned above (Preparing 2007, Main Outcomes 3), even if listed under 'modernization', stating that public administration reform should "undergo regular analysis and exchange of best practices in particular in the context of the Lisbon National Reform Programmes”.

Yet, there is a genuine ambivalence as to whether one should not rather be happy that the Lisbon Agenda did not contain any reference to public administration reform. By and large, the impression one gets when reading those texts is that even many of those who supported the Lisbon Agenda favoured NPM, while depicting classical, 'Weberian' public administration - to which they inevitably belonged - as the enemy, partially for lack of 
information regarding public administration, but often with the best intentions. But only if proper attention to public administration specifics is guaranteed, then an Open Method of Coordination-like process regarding Member States' public administration would make some sense. If so, it would therefore be important to coordinate it at the top with an office that has the capacity to deal with and focus on public administration, viz. with the commissioner in charge of public administration.

The Lisbon Agenda both requires and supports, in the sense of push/pull, the NWS and needs to change into this direction. This may be all the easier as NPM is not 'cool' anymore, but it requires a certain shift in emphasis and understanding. For the sake of the latter, the following development of concepts can be suggested:

$\begin{array}{lll}\text { Modern } & \Rightarrow & \text { Appropriate } \\ \begin{array}{l}\text { Innovative public } \\ \text { administration }\end{array} & \Rightarrow & \begin{array}{l}\text { Innovation-enabling } \\ \text { public administration }\end{array} \\ \text { Saving money } & \Rightarrow & \text { Return on investment }\end{array}$

The key to the success of any strategy like the Lisbon Agenda is to have the administrative capacity and competence of the responsive and responsible state actors to implement it. The optimal solution for this today is a genuine post-NPM system, Weberian-based but with the lessons from NPM learned, which - and this is not less right for being a cliché - puts the human person into the centre of administrative decision-making, i.e. one that is in line both with the Lisbon Agenda and its goals, with the final goal of the Good Life in the Good State. (See Drechsler 2003) "Putting knowledge into practice” (2006, p. 2) makes the one positive reference in our context to the EU's "tradition of a strong and responsible public sector, which should be capitalized on.” For the sake of the success of the Lisbon Agenda and of Europe generally, it is time that this insight is acted upon.

\section{Acknowledgments}

I would like to thank Tiina Randma-Liiv, Rainer Kattel, and Ingbert Edenhofer for comments, and Thomas Duve and Benjamin Merkler for research assistance. Support from the Gulbenkian Foundation, the Estonian Science Foundation (grant no. 7577), and the Estonian National Research Scheme (grant no. SF0140094s08) is gratefully acknowledged. 


\section{References}

Akerlof, George A. and Rachel E. Kranton (2005), "Identity and the Economics of Organizations,” Journal of Economic Perspectives, 9(1), 9-32.

Bauer, Michael W. (2006), “Die Reform der europäischen Kommission: Eine Studie zur Managementmodernisierung internationaler Organisationen,” Verwaltungsarchiv, 97(3), 270-292.

Bouckaert, Geert, Wolfgang Drechsler, and Christopher Pollitt (eds) (2009), Towards the Neo-Weberian State? Europe and Beyond, Bratislava - Tallinn: NISPAcee Press Halduskultuur, forthcoming.

Drechsler, Wolfgang (2008), “nanoGov - Nanotechnologie, Governance und Verwaltung,” In Arno Scherzberg and Joachim Wendorff (eds), Nanotechnologie - Grundlagen, Anwendungsfelder, Regulierung, Berlin - New York: de Gruyter, in press.

Drechsler, Wolfgang (2001), Good and Bad Government: Ambrogio Lorenzetti's Frescoes in the Siena Town Hall as Mission Statement for Public Administration Today, Budapest: Open Society Institute \& Local Government Initiative.

Dunleavy, Patrick, Helen Margetts, Simon Bastow and Jane Tinkler (2005), “New Public Management Is Dead - Long Live Digital-Era Governance,” Journal of Public Administraion Research and Theory, 16, 467-494.

Duve, Thomas (2008), “PA-Reformen im Rahmen der Lissabon-Strategie,” Mimeo, Tallinn University of Technology.

EPAN 2005 = “Présidence luxembourgeoise du Conseil de l’Union européenne / European Public Administration Network, Lisbon ad hoc group, "The EPAN contribution to the success of the Lisbon Strategy, Final report,” EPAN paper, at http://www.eupan.net.

EPAN 2004 = "Innovating Public Administration and the Lisbon strategy, Background document for the Ministerial Troika on 4 November 2004,” EPAN paper, at http://www.eupan.net.

Evans, Peter and James E. Rauch (1999), "Bureaucracy and Growth: A Cross-National Analysis of the Effectiveness of 'Weberian' State Structures on Economic Growth,” American Sociological Review, 64, 748-765.

Hegel, G.W.F. (1821), Grundlagen der Philosophie des Rechts, Berlin: Nicolai.

Implementation Report 2006 = "Community Lisbon Programme: Technical Implementation Report 2006,” SEC(2006) 1379.

Initiatives 2007 = "Initiatives to improve the efficiency and effectiveness of public spending: 'Modernising public administration,’” ECFIN/EPC(2007) REP/53684 rev. 2.

Kallas, Siim (2008), "Leading multicultural organisations - Developing the senior managers of the European Commission,” Halduskultur, 9, 24-29. 
König, Klaus (2001), “Zum Governance-Begriff,” in Klaus König and Markus Adam (eds), Governance als entwicklungspolitischer Ansatz, Speyer: Forschungsinstitut für öffentliche Verwaltung, pp. 1-9.

Lahti 2006 = “An innovation-friendly, modern Europe,” Communication from the Commission to the European Council (Informal Meeting in Lahti - Finland, 20 October 2006), COM(2006) 589 final.

Määttä, Seppo (2006), Looking for a Deliverable Lisbon Strategy on Sustainable Growth and Jobs. Provisional Agenda for Strategy-Focused Public Governance, [Helsinki: Finnish] Ministry of Finance.

Määttä, Seppo (2004), “The Lisbon Strategy and Strategy-Focused Public Administration,” EPAN paper, at http://www.eupan.net.

National Reform Programmes 2006 = “Member States' autumn 2006 reports on the implementation of their National Reform Programmes” at http://ec.europa.eu/growthandjobs/key/nrp2006_en.htm, with the individual country reports as pdf files.

Noordhoek, Peter and Raymdon Saner (2005), "Beyond New Public Management: Answering the Claims of Both Politics and Society,” Public Organization Review, 5, 35-53.

Perez, Carlota (2002), Technological Revolutions and Financial Capital. The Dynamics of Bubbles and Golden Ages, Cheltenham - Northampton, MA: Edward Elgar.

Pollitt, Christopher and Geert Bouckaert (2004), Public Management Reform. A Comparative Analysis, $2^{\text {nd }}$ edn, Oxford: Oxford University Press.

Preparing 2007 = Presidency of the European Union - Portugal 2007, Gabinete do PrimeiroMinistro, "Preparing the new cycle of the Lisbon Strategy."

Presidency Conclusions 2008 = Presidency Conclusions of the Brussels European Council (13/14 March 2008), CONCL1(2008) 7652/08.

Putting Knowledge 2006 = "Putting knowledge into practice: A broad-based innovation strategy for the EU,” COM(2006) 502 final.

Rochet, Claude (2007), L'innovation, une affaire d'etat, Paris: L’Harmattan.

Rodrigues, Maria João (2008), “The Lisbon Agenda and the European Governance,” Mimeo, 10 February.

Weber, Max (1922), Grundriß der Sozialökonomie, 3: Wirtschaft und Gesellschaft, Tübingen: Mohr Siebeck. 